\title{
MOTIVASI BELAJAR DAN KECAKAPAN KOMUNIKASI INTERPERSONAL TERHADAP PRESTASI BELAJAR SISWA PADA PENDIDIKAN KEWARGANEGARAAN
}

\author{
Reni Suryani \\ Fakultas Hukum Universitas Pamulang \\ Email:renysrn@yahoo.co.id
}

\section{Received: Jun 2019/Revised: Jun 2019/Accepted: Ags 2019}

\begin{abstract}
Pengaruh Motivasi Belajar dan Kecakapan Komunikasi Interpersonal Terhadap Presstasi Belajar Siswa Pada Pelajaran Pendidikan Kewarganegaraan (Survey Pada SMP Swasta Di Kecamatan Pamulang Tangerang Selatan); Tesis; Jakarta; Program Pascasarjana; Universitas Indraprasta Peratuan Guru Republik Indonesia, Januari 2015. Tujuan dari penelitian ini adalah untuk mengehui sejauh mana pengaruh motivasi belajar dan kecakapan komunikasi interpersonal terhadap prestasi belajar siswa terutama siswa SMP pada mata pelajaran Pendidikan Kewarganegaraan (PKn). Jika memang ada pengaruh yang positif dan signifikan, maka seberapa kuat pengaruh motivasi belajar dan kecakapan komunikasi interpersonal terhadap prestasi belajar. Metode penelitian yang digunaka adalah survei dengan analisis korelasi dan regresi, yaitu menghubungkan antara data yang menunjukkan motivasi belajar dan kecakapan komunikasi interpersonal dengan data yang menunjukkan prestasi belajar siswa pada mata pelajaran Pendidikan Kewarganegaraan (PKn).

Kata Kunci : Pemerintah Daerah, Wilayah Pesisir, Pulau-Pulau Kecil.
\end{abstract}

\section{ABSTRACT}

The Effect of Learning Motivation and Interpersonal Communication Skills on Student Learning Achievement in Citizenship Education Lessons (Survey at Private Middle School in Pamulang District, South Tangerang); Thesis; Jakarta; Graduate program; Indraprastha University Teacher Association of the Republic of Indonesia, January 2015. The purpose of this study was to determine the extent of the influence of learning motivation and interpersonal communication skills on student learning achievement, especially junior high school students in Civics Education. If indeed there is a positive and significant influence then how strong is the influence of learning motivation and interpersonal communication skills on learning achievement. The research method used is a survey with correlation and regression analysis, which connects data that shows learning motivation and 
interpersonal communication skills with data that shows student learning achievement in the eyes. Civics Education Learning (PKn).

Keywords: learning motivation, interpersonal communication skills, learning achievement in civic education (PKn).

\section{PENDAHULUAN}

Indonesia memerlukan sumber daya manusia dalam jumlah dan mutu yang memadai sebagai pendukung utama dalam pembangunan. Pendidikan merupakan suatu kegiatan yang universal dalam kehidupan manusia, karena dimanapun dan kapanpun di dunia terdapat pendidikan. Pendidikan pada hakikatnya merupakan usaha manusia untuk memanusiakan manusia itu sendiri, yaitu untuk membudayakan manusia.

Hal ini sesuai dengan UU No 20 Tahun 2003 Tentang Sistem Pendidikan Nasional pada Pasal 3 yang menyebutkan bahwa 'Pendidikan Nasional berfungsi mengembangkan kemampuan dan membentuk karakter serta peradaban bangsa yang bermartabat dalam rangka mencerdaskan kehidupan bangsa'. Permasalahan yang dihadapi oleh peserta didik didalam prestasi belajar Kewarganegaraan adalah kurangnya motivasi membaca buku pelajaran, penyampaian materi oleh guru dan jumlah jam pelajaran Kewarganegaraan yang hanya 3 x 40 menit dalam seminggu.

Pendidikan Kewarganegraan (PKN) bertujuan untuk mengembangkan pengetahuan dan kemampuan peserta didik dalam memahami dan menghayati nilai-nilai Pancasila dalam rangka pembentukan sikap dan prilaku sebagi pribadi, anggota masyarakat, dan warga Negara yang bertanggung jawab, berkembang secara positif dan demokratis untuk membentuk diri berdasarkan pada karakter. Melalui mata pelajaran Kewarganegaraan, peserta didik diarahkan untuk dapat menjadi warga Negara Indonesia yang demokratis dan bertanggungjawab serta warga dunia yang cinta damai. Dimasa yang akan datang peserta didik akan menghadapi tantangan berat karena kehidupan masyarakat global selalu mengalami perubahan setiap saat.

Menyadari akan manfaat Kewarganegaraan yang demikian kompleks tersebut, idealnya tingkat pemahaman pada mata pelajaran Kewarganegaraan pada tataran sekolah harus memuaskan. Namun kenyataannya dilapangan, dewasa ini pelajaran Kewarganegraan dipelajari peserta didik hanya sekedar untuk mendapatkan nilai raport, syarat kenaikkan kelas, dan atau kelulusan sich. Siswa belajar hanya untuk sekolah bukan untuk hidup (life skills). Hal ini harus disadari betul bahwa 
sesungguhnya siswa belajar bukan untuk sekolah melainkan untuk hidup (vital non scholae discimus).

Dari uraian di atas mendorong peneliti untuk melakukan penelitian dengan judul “Pengaruh Motivasi Belajar dan Kecakapan komunikasi interpersonal Terhadap Prestasi Belajar Kewarganegaraan SMP Islam Swasta di Kecamatan Pamulang Tangerang Selatan.”

\section{PERMASALAHAN}

Berdasarkan latar belakang penelitian diatas dapat diidentifikasi masalah-masalah sebagai berikut :

I. Mengapa prestasi belajar siswa pada mata pelajaran Pendidikan Kewarganegaraan $(\mathrm{PKn})$ masih rendah?

2. Apa saja yang mempengaruhi prestasi belajar siswa pada mata pelajaran Pendidikan Kewarganegaraan ( $\mathrm{PKn})$ ?

3. Apakah faktor eksternal siswa yang lebih dominan mempengaruhi prestasi belajar siswa pada mata pelajaran PKn?

\section{METODOLOGI PENELITIAN}

Metode pengumpulan data yang digunakan untuk menunjang dan memperkaya penelitian ini adalah, dengan : I. Metode pendekatan survey deskriptif Yaitu suatu suatu metode penelitian yang mengambil sampel dari suatu populasi dan menggunakan kuesioner sebagai alat pengumpulan data. Dalam penelitian ini data dan informasi dikumpulkan dari responden dengan menggunakan kuesioner. Setelah data diperoleh kemudian hasilnya akan dipaparkan secara deskriptif dan pada akhir penelitian akan dianalisis untuk menguji hipotesis yang diajukan pada awal penelitian ini (Effendi, 2003: 3). Metode penelitian survey adalah usaha pengamatan untuk mendapatkan keterangan-keterangan yang jelas terhadap suatu masalah tertentu dalam suatu penelitian. Penelitian dilakukan untuk suatu tindakan yang sifatnya deskriptif yaitu melukiskan hal-hal yang mengandung fakta-fakta, klasifikasi dan pengukuran yang akan diukur adalah fakta yang fungsinya merumuskan dan melukiskan apa yang terjadi (Ali, 1997:5). 2. Sumber Data Sumber data untuk variabel motivasi belajar dan kecakapan komunikasi interpersonal adalah jawaban responden (siswa) atas butir-butir pertanyaan yang ada dalam angket/kuisener yang diberikan oleh peneliti. Sedangkan untuk variabel prestasi belajar PKn sumber datanya adalah nilai hasil tes yang dilkasanakan langsung oleh peneliti kepada responden, yaitu berupa ulangan tertulis dengan materi yang sesuai dengan materi pembelajaran di 
kelas 3. Metode Pengumpulan/ Mandapatkan Data Untuk mendapatkan data tentang motivasi belajar dan kecakapan komunikasi interpersonal adalah dengan meminta responden untuk menjawab butirbutir pertanyaan yang ada dalam angket/kuisener yang diberikan oleh peneliti. Jawaban responden tersebut kemudian diberi skor sesuai dengan ketentuan penskoran yang ada pada angket. Sedangkan teknik mendapatkan data tentang prestasi belajar adalah dengan melaksanakan tes/ulangan tertulis langsung kepada responden.

\section{PEMBAHASAN}

\section{Hakikat Prestasi Belajar Pendidikan Kewarganegaraan}

Untuk lebih memahami pengertian belajar, maka berikut definisidefinisi tentang belajar dari pendapat para ahli psikologi, yaitu antara lain :

Hamalik, belajar adalah modifikasi atau memperteguh kelakuan melalui pengalaman (learning is defined as the modification or strengthening of behavior through experiencing). Menut pengertian ini, belajar merupakan suatu proses,suatu kegiatan,dan bukan suatu hasil atau tujuan. Slameto ,menyatakan belajar adalah suatu proses usaha yang dilakukan seseorang untuk memperoleh perubaan tingkah laku yang baru secara keseluruhan, sebagai hasil pengalaman sendiri dan interaksi lingkungannya. ${ }^{r}$ Menurut Lestari, "belajar adalah serangkaian kegiatan jiwa dan raga untuk memperoleh suatu perubahan tingkah laku sebagai hasil dari pengalaman individu dalam interaksi dengan lingkungannya yang meyangkut ranah kognotif, afektif, dan psikomotor." ${ }^{2}$

Sardiman A.M mengatakan belajar adalah sebagai suatu perubahan tingkah laku karena hasil dari pengalaman yang diperoleh. ${ }^{3}$ Gagne menyatakan belajar adalah suatu proses dimana organisme berubah perilakunya sebagai akibat pengalaman. Campbell Bruce menyatakan bahwa belajar adalah aktifitas mental yang berlangsung dalam interaksi anak dengan lingkungan yang menghasikan perubahan dalam pengetahuan, pemahaman, keterampilan sikap dan nilai. Agar proses belajar dapat berjalan dengan baik, salah satu inti adalah pengajaran itu harus bermakna bagi siswa, artinya informasi baru atau materi baru yang akan diajarkan harus dikaitkan dengan apa yang telah diketahui siswa, sehingga siswa dapat merespon pengajaran yang diberikan, sebab berkaitan dengan informasi baru dengan pengetahuan yang dimiliki siswa akan

\footnotetext{
Rineke Cipta

${ }^{2}$ Lestari, Sudi, (2010:26) Teori dan Prinsip Pendidikan, Jakarta : Rieneka Cipta

${ }^{3}$ Sardiman, AM, Interaksi dan motivasi belajar mengajar, Jakarta, CV Rajawali
}

${ }^{1}$ Slamento, (2003:3). Belajar dan faktor-faktor yang mempengaruhinya, Jakarta 
menumbuhakan rasa ingin mengetahui, menanggapi dan rasa ingin bertanya. 4

Dimyati dan Mudjiono (2009 : 7), belajar adalah penambahan pengetahuan, belajar membawa sesuatu perubahan pada individu yang berlajar secara teratur dan terencana serta menggunakan tehknik tertentu sesuai dengan ilmu yang dipelajari. Belajar merupakan tindakan dan perilaku siswa yang komplek. Sebagai tindakan ,maka belajar hanya dialami oleh siswa sendiri. Siswa adalah penentu terjadinya atau tidak terjadinya proses belajar. Proses belajar berkait dengan siswa memperoleh sesuatu yang ada di lingkungan sekitarnya. lingkungan yang dipelajari oleh siswa berupa keadaan alam, benda benda, hewan tubuhan, manusia atau hal- hal yang dijadikan bahan ajar. ${ }^{5}$

Berikut definisi tentang belajar dari pendapat beberapa ahli yang dikutip oleh Ngalim Purwanto (1997: $84-86)^{6}$

I. Chonbach memberikan definisi : Learning is shown by a change in behavior as a result of experience.

2. Gagne dalam bukunya The Condition of Learning (1977 : 45), menyatakan "Bahwa belajar terjadi apabila suatu situasi stimulus bersama dengan ingatan mempengaruhi siswa sedemikian rupa sehingga perbuatannya (pefomance-nya) berubah dari waktu sebelum ia mengalami situasi itu ke waktu sesudah ia mengalami situasi tadi “

3. Morgan, dalam bukunya Introduction to psycology (I98I : 125), mendefinisikan belajar sebagai setiap perubahan yang relatif menetap dalam tingkah laku yang terjadi sebagai hasil latihan atau pengalaman ${ }^{7}$.

Dari definisi-definisi yang dikemukakan di atas, dapat dikemukakan adanya elemen yang penting yang mencirikan pengertian tentang belajar, yaitu bahwa :

I. Belajar merupakan suatu perubahan dalam tingkah laku, dimana perubahan itu dapat mengarah kepada tingkah laku yang lebih baik, tetapi juga ada kemungkinan mengarah kepada tingkah laku yang lebih buruk.

\footnotetext{
${ }^{4}$ Gegne (1998:151) Essential of Learning for Instruction, Newjetsj

${ }^{5}$ Dimiati dan Marjiono (2009:7) Belajar dan Pembelajaran

${ }^{6}$ Purwanto, M Ngalim 2000 Ilmu Pendidikan Teoritis dan Praktis Bandung, PT Remaja Risdakarya

${ }^{7}$ Iqbal, Muhamad. "Perkembangan Kejahatan Dalam Upaya Penegakan Hukum Pidana: Penanggulangan Kejahatan Profesional Perdagangan Organ Tubuh Manusia." PROCEEDINGS. Vol. 2. No. 1. 2017.
} 
2. Untuk dapat disebut belajar, maka perubahan itu harus relatif mantap; harus merupakan akhir dari suatu periode waktu yang cukup panjang. Berapa lama periode waktu itu berlangsung sulit ditentukan dengan pasti, tetapi perubahan itu hendaknya merupakan akhir dari suatu periode yang mungkin berlangsung berhari-hari, berbulan-bulan, ataupun bertahun-tahun. Ini berarti kita harus mengenyampingkan perubahan tingkah laku yang disebabkan oleh motivasi, kelelahan, adaptasi, ketajaman perhatian atau kepekaan seseorang, yang biasanya hanya berlangsung sementara.

Belajar merupakan suatu perubahan yang terjadi melalui latihan atau pengalaman; dalam arti perubahan-perubahan yang disebabkan oleh pertumbuhan atau kematangan tidak dianggap sebagai prestasi belajar seperti perubahan-perubahan yang terjadi pada diri seorang bayi.

Tingkah laku yang mengalami perubahan karena belajar menyangkut berbagai aspek kepribadian, baik fisik maupun psikis, seperti : perubahan dalam pengertian, pemecahan suatu masalah / berpikir, keterampilan, kecakapan, kebiasaan, ataupun sikap.

Dalam pengertian lain, belajar adalah terminologi yang digunakan untuk menggambarkan proses yang meliputi perubahan melalui pengalaman. Proses perubahan tersebut secara relatif untuk memperoleh perubahan permanen dalam pemahaman sikap, pengetahuan, informasi, kemampuan dan keterampilan melalui pengalaman.

Winkel (1999 : 53) ${ }^{8}$ mengemukakan bahwa belajar dirumuskan sebagai suatu aktivitas mental/psikis, yang berlangsung dalam interaksi aktif dengan lingkungan yang menghasilkan perubahan-perubahan dalam pengetahuan-pemahaman, keterampilan dan nilai-sikap. Menurut Muizudin (2003 :15)9: "Belajar adalah merupakan perubahan tingkah laku, sifat dan kemampuan yang relatif permanen, yang datang dari dalam diri siswa, dan dapat ditinjau terutama dari pengaruh lingkungan atau dari faktor genetis yang berbeda satu dengan yang lainnya."

Belajar dapat didefinisikan, "Suatu usaha atau kegiatan yang bertujuan mengadakan perubahan di dalam diri seseorang, mencakup perubahan tingkah laku, sikap, kebiasaan, ilmu pengetahuan, keterampilan

${ }^{8}$ Wnkel (1999:53) WS 1999 Psikologi Pengajaran, Edisi yang disempurnakan, Cetakan ke 4, Jakarta:Grasindo

${ }^{9}$ Muzizudin (2003:15) Pengaruh Pemberian Evaluasi Formatif terhadap Belajar ditinjau dari sikap siswa terhadap mata pelajaran, Tesis Jakara UNJ 
dan sebagainya. ${ }^{\text {ro }}$ Dari pengertian tersebut dapat diambil kesimpulan bahwa belajar adalah suatu usaha yang dilakukan secara sadar dan sungguh-sungguh, dengan sistematis, mendayagunakan semua potensi yang dimiliki baik aspek fisik maupun psikis yang bertujuan untuk mendapatkan perubahan di dalam diri baik pengetahuan, keterampilan maupun sikap atau tingkah laku.

\section{Pengertian Prestasi Belajar}

Definisi Prestasi belajar menurut Sudjana (2009 : 22) "I adalah kemampuan-kemampuan yang dimiliki siswa setelah ia menerima pengalaman belajarnya. Kemudian menurut Kingsley (dalam Sudjana, 2009 : 22) mengatakan bahwa belajar dan mengajar sebagai suatu proses mengandung tiga unsur yaitu, (a) keterampilan dan kebiasaan, (b) pengetahuan dan pengertian, (c) sikap dan cita-cita. yang dapat dibedakan, yakni tujuan pengajaran (instruksional), pengalaman (proses) belajar mengajar, dan prestasi belajar.

Menurut Benyamin S. Bloom, dkk. (dalam Zainal Arifin, 20II : 2I), prestasi belajar dapat dikelompokkan menjadi tiga ranah, yaitu : domain kognitif, psikomotor, dan afektif. Secara eksplisit tiga domain itu tidak dapat dipisahkan. Setiap pelajaran selalu mengandung tiga domain tersebut, namun penekanannya selalu berbeda. Adapun rincian domain tersebut adalah sebagai berikut : Domain Kognitif (cognitive domain). Domain ini memiliki enam jenjang kemampuan, yaitu :

a) Pengetahuan (Knowledge), yaitu kemampuan yang menuntut peserta didik untuk dapat mengenali atau mengetahui adanya konsep, prinsip, fakta, atau istilah tanpa harus mengerti atau dapat menggunakannya.

b) Pemahaman (comprehension), yaitu jenjang kemampuan yang menuntut peserta didik untuk memahami atau mengerti tentang materi pelajaran yang disampaikan guru dan dapat memanfaatkannya tanpa harus menghubungkannya dengan hal-hal lain.

c) Penerapan (Application), yaitu jenjang kemampuan yang menuntut peserta didik untuk menggunakan ide-ide umum, tata cara ataupun metode, prinsip dan teori-teori dalam situasi baru dan konkrit.

\footnotetext{
${ }^{10}$ Iqbal, Muhamad. "IMPLEMENTASI EFEKTIFITAS ASAS OPORTUNITAS DI INDONESIA DENGAN LANDASAN KEPENTINGAN UMUM." Jurnal Surya Kencana Satu: Dinamika Masalah Hukum dan Keadilan 9.1 (2018).

${ }^{11}$ Sujana, nana (2004) (dalam 2009) Dasar-dasar Proses Belajar mengajar, Bandung; Sinar Baru
} 
d) Analisis (analysis), yaitu kemampuan yang menuntut peserta didik untuk menguraikan suatu situasi atau keadaan tertentu ke dalam unsur-unsur atau komponen pembentuknya, atau suatu pola pikir yang bersifat deduktif.

e) Sintesis (synthesis) yaitu jenjang kemampuan yang menuntut peserta didik menghasilkan sesuatu yang baru dengan menggabungkan berbagai faktor. Hasil yang didapat bisa berupa tulisan, rencana, atau mekanisme, atau suatu pola pikir yang bersifat deduktif.

f) Evaluasi (evaluation), yaitu jenjang kemampuan yang menuntut peserta didik untuk dapat mengevaluasi suatu situasi, keadaan, pernyataan atau konsep berdasarkan kriteria tertentu.

g) Domain Afektif (affective domain), yaitu internalisasi sikap yang menunjuk ke arah pertumbuhan batiniah dan terjadi ketika peserta didik menjadi sadar tentang nilai yang diterima, kemudian mengambil sikap sehingga menjadi bagian dari dirinya dalam membentuk nilai dan menentukan tingkah laku.

h) Domain afektif terdiri atas beberapa jenjang kemampuan, yait Kemauan menerima (receiving), yaitu jenjang kemampuan yang menuntut peserta didik untuk peka terhadap eksistensi fenomena atau ransangan tertentu.

i) Kemauan menanggapi/menjawab (responding), yaitu jenjang kemauan yang menuntut peserta didik untuk bereaksi terhadap salah satu cara, menjawab secara sukarela, membaca tanpa ditugaskan.

j) Menilai (valuing), yaitu jenjang kemampuan yang menuntut peserta didik menilai suatu objek, fenomena, dan/atau kejadian tertentu secara konsisten.

k) Organisasi (organization), yaitu jenjang kemampuan yang menuntut peserta didik untuk menyatukan nilai-nilai yang berbeda, memecahkan masalah, membentuk suatu sistim nilai, membangun suatu kesatuan dari komponen-komponen yang terpisah.

1) Domain Psikomotor (psychmotor domain), yaitu kemampuan peserta didik yang berkaitan dengan gerakan tubuh atau bagian-bagiannya, mulai dari gerakan yang sederhana sampai gerakan yang kompleks.

Dari beberapa teori yang disebutkan, maka dapat disimpulkan bahwa prestasi belajar adalah perubahan tingkah laku, sifat dan kemauan yang berupa penguasaan dalam pengetahuan, sikap dan nilai serta keterampilan yang bersifat relatif tetap sebagai hasil latihan. 
Pendidikan Kewarganegaan (PKn)

\section{Pengertian Pendidikan Kewarganegaraan (PKn)}

Pendidikan Kewarganegaraan (citizenship) merupakan mata pelajaran yang memfokuskan pada pembentukan diri yang beragam dari segi agama, social-budaya, bahasa, usia, dan suku bangsa untuk menjadi warga negara Indonesia yang cerdas, terampil, dan berkarakter yang dilandasi oleh Pancasila dan UUD 1945. Menurut Aim Abdulkarim (2007: 3), ${ }^{12}$ fungsi Pendidikan Kewarganegaraan adalah sebagai wahana untuk membentuk warga Negara yang baik (to be good citizenship), cerdas, trampil, dan berkarakter setia kepada bangsa dan Negara Indonesia dengan merefleksikan diri dalam kebiasaan berfikir dan bertindak sesuai Pancasila dan UUD 1945.

Dengan adanya PKn selain kita dapat memahami hak dan kewajiban sebagai warga Negara, kita dapat mengembangkan kemampuankemampuan sebagai berikut:

I) Berpikir kritis, rasional, dan kreatif dalam menghadapi berbagai masalah kewarganegaraan.

2) Berkembang secara positif dan demokratis untuk membentuk

diri berdasarkan pada karakter masyarakat Indonesia.

3) Berpartisipasi aktif dan bertanggung jawab, serta bertindak secara cerdas dalam kegiatan bermasyarakat, berbangsa, dan bernegara.

4) Berinteraksi dengan bangsa-bangsa lain dalam percaturan dunia secara langsung atau tidak langsung dengan menggunakan informasi dan komunikasi.

PKn merupakan praktek belajar kewarganegaraan sebagai inovasi pembelajaran untuk memahami teori secara mendalam melalui pengalaman belajar dengan life skill (kecakapan hidupnya). Sehingga pada hakikatnya PKn adalah upaya sadar dan terencana untuk mencerdaskan kehidupan bangsa bagi warga negara dengan menumbuhkan jati diri dan moral bangsa sebagai landasan pelaksanaan hak dan kewajiban dalam bela negara, demi kelangsungan kehidupan dan kejayaan bangsa dan negara.

\section{Fungsi Pendidikan Kewarganegaraan}

Pendidikan Kewarganegaraan berfungsi dalam:

a) Mengembangkan dan melestarikan nilai dan moral Pancasila dalam kehidupan sehari-hari.

b) Mengembangkan dan membina siswa sebagai manusia Indonesia

${ }^{12}$ Abdulkarim Aim 2007 Kewarganegaraan, Jakarta, Pustaka Ilmu 
seutuhnya yang sadar akan hak dan kewajiban taat pada peraturan hukum yang berlaku, serta berbudi pekerti yang luhur.

Membina siswa agar memahami dan menyadari hubungan antar sesama anggota keluarga sekolah, dan masyarakat serta dalam kehidupan berbangsa dan bernegara.

\section{Tujuan Pendidikan Kewarganegaraan}

Dalam buku materi pelajaran Pendidikan Kewarganegaraan (Depdiknas, 2006: 4) ${ }^{\text {i3 }}$ tujuan pendidikan kewarganegaraan adalah mewujudkan warga negara sadar bela negara berlandaskan pemahaman politik kebangsaan, dan kepekaan mengembangkan jati diri dan moral bangsa dalam peri kehidupan bangsa. Lebih lanjut PKn di SMP bertujuan meningkatkan pengetahuan dan mengembangkan kemampuan, memahami, menghayati dan meyakini nilai-nilai moral Pancasila sebagai pedoman perilaku dalam kehidupan bermasyarakat, berbangsa dan bernegara, sehingga menjadi warga negara yang bertanggung jawab dan dapat diandalkan serta berstudi lanjut pada tingkat yang lebih tinggi.

\section{Ruang Lingkup Pendidikan Kewarganegaraan}

Nilai dan norma bangsa Indonesia serta yang diharapkan terwujud dalam kehidupan bermasyarakat, berbangsa. Kehidupan ideologi, politik, ekonomi, sosial, budaya, pertahanan dan keamanan di negara republik Indinesia yang berdasarkan Pancasila dan Undang-Undang Dasar 1945. Sedangkan luas liputan, kedalaman, tingkat kesukaran materi pelajaran sesuai dengan tingkat perkembangan belajar siswa pada satuan pendidikan yang bersangkutan sebagaimana tercantum dalam perencanaan program pengajaran.

Guru harus mampu memilih secara tepat jenis instrumen mana yang harus dipilih untuk Mengingat Pendidikan Kewarganegaraan terdiri dari aspek kognitif, afektif dan psikomotor maka penilaian Pendidikan Kewarganegaraan juga mencakup tiga komponen tersebut melakukan penilaian secara tepat.

\section{Pengertian Prestasi belajar Pelajaran Pendidikan Kewarganegaraan}

Prestasi belajar atau achievement merupakan salah satu prestasi belajar yang diukur sebagai salah satu tujuan pengajaran. Menurut

\footnotetext{
${ }^{13}$ Depdiknas (2006:4) Pendidikan Kewarganegaraan
} 
Setiawati (1996:28)14 : "Selain achievement (prestasi belajar), hasil dari proses pengajaran yang lain adalah sikap, minat dan kepribadian”.

Mata pelajaran Pendidikan Kewarganegaraan merupakan salah satu mata pelajaran di sekolah yang menekankan pada pembelajaran tentang kehidupan manusia dan lingkungan sosial masyarakat di sekitarnya terutama yang berkaitan dengan usaha manusia dalam memenuhi hajat hidupnya. Belajar ilmu kewarganegaraan sama artinya dengan pembelajaran tentang sosial masyarakat. pendidikan kewarganegaraan memiliki objek pembelajaran yang terkait dengan manusia dan semua peristiwa yang terjadi dalam lingkungan sosial masyarakat. Oleh karena itu, belajar ilmu pendidikan kewarganegaraan pun perlu diukur tingkat keberhasilannya melalui prestasi belajar yang diperoleh siswa. Prestasi belajar ilmu PKn mencapuk bagian akhir diri proses pembelajaran ilmu pendidikan kewarganegaraan yang dilakukan di sekolah. Dengan prestasi belajar ilmu pendidikan kewarganegaraan, siswa dapat mengetahui kemampuan dan pemahaman yang terkait dengan materi pembelajaran.

Prestasi belajar PKn pada dasarnya dapat terlihat melalui perubahan tingkah laku siswa dalam memandang dan memahami ilmu pendidikan kewarganegaraan. Oemar Hamalik (2010 : 30) ${ }^{\text {15 }}$ menyatakan bahwa hasil seseorang belajar adalah tenjadinya perubahan tingkah laku dan kemampuan kognitif siswa, seperti dari tidak tahu menjadi tahu. Oleh karena itu, Prestasi belajar pendidikan kewarganegaraan harus dapat menjadi indikator untuk mengukur kemampuan dan penguasaan siswa terhadap berbagai materi yang dipelajari dalam ilmu pendidikan kewarganegaraan.

Pembelajaran ilmu PKn menekankan pada kemampuan siswa dalam mengamati, menganalisis, dan menerapkan ilmu yang berkaitan dengan manusia dengan lingkungan sosial masyarakat sekitarnya. Pembelajaran ilmu pendidikan kewarganegaraan tidak hanya terbatas pada penguasaan terhadap pengetahuan ilmu pendidikan kewarganegaraan semata, tetapi juga harus diikuti dengan upaya untuk menerapkannya dalam mengamati manusia dengan segala proses sosial dalam pemenuhan hajat hidupnya yang menyertainya. prestasi belajar ilmu PKn juga tercermin melalui pengetahuan dan keterampilan siswa dalam memecahkan setiap masalah yang terkait dengan pelajaran pendidikan kewarganegaraan, serta tercermin melalui sikap siswa dalam kehidupan sehari-hari yang terkait dengan wawasannya tentang ilmu PKn.

${ }^{14}$ Setiawati NT (1996:28) Memupuk dan kreatifitas Siswa Sekolah Menengah Jakarta, Gramedia

${ }^{15}$ Hamalik, Oemar (2010:30) Proses belajar mengajar, Jakarta : Bumi Aksara 
Dari uraian di atas dapat disimpulkan bahwa prestasi belajar pendidikan kewarganegaraan adalah tingkat pencapaian kemampuan pengetahuan siswa pada materi ilmu pendidikan kewarganegaraan, serta pencapaian keterampilan dan sikap yang terkait dengan wawasan tentang ilmu pendidikan kewarganegaraan.

\section{Hakikat Motivasi Belajar}

\section{Pengertian Motivasi}

Motivasi sering diartikan sebagai suatu dorongan yang menggerakan seseorang. Menurut Malayu S.P Hasibuan (2010: I4I) ${ }^{16}$ asal kata motivasi yaitu :

Motivasi dari kata "movere" yang berarti dorongan atau menggerakkan. Motivasi sangat diperlukan dalam pelaksanaan aktivitas manusia karena motivasi merupakan hal yang dapat menyebabkan,menyalurkan dan mendukung perilaku manusia supaya mau bekerja giat dan antusias untuk mencapai hasil yang optimal. Menurut $G$ R Terry yang diterjemahkan oleh Robbert Gagne (1998 :130), "motivasi dapat diartikan sebagai suatu usaha agar seseorang dapat menyelesaikan pekerjaannya dengan semangat karena ada tujuan yang ingin dicapai”. Djamarah (2008:114) mengemukakan bahwa "motivasi adalah suatu perubahan energi di dalam pribadi seseorang yang ditandai dengan timbulnya afektif (perasaan) dan reaksi untuk pencapaian tujuan”.

Motivasi merupakan dorongan, hasrat, dan penggerak lainnya yang berasal dari dalam diri manusia, untuk melakukan sesuatu. Motivasi memberi tujuan dan arah kepada tingkah laku manusia. Purwanto (2010:71) menyatakan bahwa "motivasi adalah pendorongan, suatu usaha yang didasari untuk mempengaruhi tingkah laku seseorang agar ia tergerak hatinya untuk bertindak melakukan sesuatu sehingga mencapai hasil atau tujuan tertentu".

Dari uraian tersebut dapat tergambar, bahwa konsep motivasi dapat disimpulkan sebagai berikut : motivasi merupakan suatu kekuatan yang dapat mendorong seseorang untuk berbuat atau melakukan sesuatu. Istilah motivasi sering digunakan secara bergantian dengan kebutuhan, keinginan, dan dorongan. Munculnya motivasi pada seseorang karena terpicu atas kebutuhan, kemudian terdorong untuk memenuhinya.

\section{Pengertian Motivasi Belajar}

${ }^{16}$ Hasibuan Malayu SP (2010 141) Manajemen Sumber Daya Manusia, Jakarta Bumi Aksara 
Dalam kaitannya dengan belajar, motivasi sangat erat hubungannya dengan kebutuhan aktualisasi diri sehingga motivasi paling besar pengaruhnya pada kegiatan belajar siswa yang bertujuan untuk mencapai prestasi belajar yang maksimal. Menurut Hamzah B. Uno (2007: 23), ${ }^{17}$ motivasi belajar dapat timbul karena faktor intrinsik, berupa hasrat dan keinginan berhasil dan dorongan kebutuhan belajar, harapan akan cita-cita. Sedangkan faktor ekstrinsiknya adalah adanya penghargaan, lingkungan belajar yang kondusif, dan kegiatan belajar yang menarik.

Hakikat motivasi belajar adalah dorongan internal dan eksternal pada siswa yang sedang belajar untuk mengadakan perubahan tingkah laku, pada umumnya dengan menggunakan indikator atau unsur yang mendukung. Hamzah B. Uno (2007: 23) mengklasifikasikan indikator motivasi belajar sebagai berikut: (I) adanya hasrat dan keinginan berhasil; (2) adanya dorongan dan kebutuhan dalam belajar; (3) adanya harapan dan cita-cita masa depan; (4) adanya penghargaan dalam belajar; (5) adanya kegiatan yang menarik dalam belajar; (6) adanya lingkungan belajar yang kondusif, sehingga memungkinkan seorang siswa dapat belajar dengan baik.

Apabila tidak ada motivasi belajar dalam diri siswa, maka akan menimbulkan rasa malas untuk belajar baik dalam mengikuti proses belajar mengajar maupun mengerjakan tugas-tugas individu dari guru. Orang yang mempunyai motivasi yang tinggi dalam belajar maka akan timbul minat dan kemandirian belajar yang besar dalam mengerjakan tugas, membangun sikap dan kebiasaan belajar yang sehat melalui penyusunan jadwal belajar dan melaksanakannya dengan tekun. Hal tersebut sejalan dengan pendapat Clayton Alderfer dalam Hamzah B. Uno (2007 : 42) mengungkapkan bahwa "motivasi belajar adalah kecenderungan siswa dalam melakukan kegiatan belajar yang didorong oleh hasrat untuk mencapai prestasi atau prestasi belajar sebaik mungkin”. Motivasi belajar ini juga didukung teori kebutuhan aktualisasi diri (self actualization) oleh Abraham Maslow, yaitu kebutuhan untuk mengembangkan kemampuan diri secara optimum, sehingga mampu berbuat yang lebih baik, berprestasi, dan kreatif. Kemudian juga didukung teori kebutuhan untuk berkembang (growth needs) oleh Clyton Alderfer dalam Tabrani (1999 : 23), kebutuhan setiap orang untuk tumbuh dan berkembang dalam hidup dan kehidupannya, seperti peningkatan profesi dan prestasi, termasuk kemampuan berkreasi (kreativitas).

${ }^{17}$ Uno H Hamzaah B 2007 Profesi kependidikan problema, solusi dan reformasi pendidikan di Indonesia, Jakarta : Bumi Aksara 
Jadi motivasi belajar dalam hal ini dapat disimpulkan sebagai keseluruhan daya penggerak psikis dalam diri siswa yang menimbulkan kegiatan belajar, menjamin kelangsungan belajar demi mencapai satu tujuan. Orang mempunyai dorongan kuat untuk berhasil meraih prestasi pribadi. Mereka mempunyai hasrat untuk melakukan sesuatu dengan lebih baik atau lebih efisien daripada yang telah dilakukan sebelumnya, dorongan ini adalah kebutuhan untuk berprestasi. Kebutuhan afiliasi merupakan hasrat untuk disukai orang lain atau diterima baik oleh orang lain. Sedangkan kebutuhan kekuasaan merupakan hasrat untuk dapat menguasai orang lain. Namun yang dimaksud kekuasaan disini bukan yang bersifat diktaktor dan untuk kepentingan pribadi. Motivasi berkuasa ini lebih mengarah kepada kebutuhan untuk memiliki pengaruh dan efektifitas dalam mencapai tujuan bersama.

Untuk menumbuhkan motivasi belajar yang kuat di sekolah pada diri peserta didik dapat dilakuakan dengan beberapa cara. Menurut Sardiman (2010: 92) "untuk menumbuhkan motivasi belajar antara lain, memberi angka, hadiah, saingan/kompetisi, ego-involment, memberi ulangan, mengetahui hasil, pujian, hukuman, hasrat untuk belajar, minat, serta tujuan yang diakui”.

Dari paparan diatas tadi dapat kita tarik kesimpulan bahwa motivasi belajar adalah daya penggerak yang mendorong, mengarahkan dan mempertahankan siwa untuk melakukan aktivitas belajar. Motivasi dalam hal ini dapat berupa motivasi instrinsik yang berasal dari dalam diri siswa itu sendiri, dan motivasi ekstrinsik yag berasal dari luar diri siswa. Motivasi belajar siswa dapat dilihat dari beberapa dimensi yaitu orientasi tujuan, minat dan emosi.

\section{Kecakapan Komunikasi Interpersonal \\ Pengertian Kecakapan}

Menurut kamus Besar Bahasa Indonesia, kecakapan berasal dari kata cakap berarti pandai, mampu pintar atau bisa mengerjakan. Inter atau Antar bermakna penengah, yang menjembatani atau yang menengahi, sedangkan personal berarti perseorangan bersifat tunggal (singular) bukan jamak (plural). Jadi kecakapan komunikasi interpersonal atau kecakapan antar personal bisa diartikan sebagai kepandai atau kemampuan seseorang untuk menjembatani antar pribadi. Menjembatani antar pribadi maksudnya adalah menghubungkan antara diri pribadi dengan orang lain. Hubungan yang dimaksud disini diartikan sebagai hubungan sosial antara seseorang dengan orang lain yang diistilahkan dengan kata komunikasi. 
Jadi kecakapan komunikasi interpersonal adalah kemampuan seseorang untuk berkomunikasi dengan orang lain.

Menurut Riyono Praktiko (1987:16), kecakapan komunikasi interpersonal adalah kemampuan yang dimiliki dan digunakan oleh seseorang untuk berinteraksi secara benar dengan orang lain. Di lingkungan kerja, istilah kecakapan komunikasi interpersonal mengacu pada kemampuan karyawan untuk bergaul dengan orang lain dalam menyelesaikan pekerjaannya sendiri atau pekerjaan bersama, atau dalam rangka untuk mendapatkan pekerjaan. Kecakapan komunikasi interpersonal meliputi segala sesuatu dari komunikasi dan keterampilan mendengarkan, sikap dan tingkah laku dan kemampuan untuk memproyeksikan sikap positif dan mencari solusi suatu masalah.

Dari uraian di atas bisa diperhatikan bahwa hal utama yang dibahas dalam kecakapan komunikasi interpersonal adalah kemampuan yang dimiliki seseorang untuk melakukan komunikasi dan interaksi dengan orang lain.

\section{Pengertian Komunikasi}

Selain sebagai mahluk individu, manusia juga terlahir sebagai mahluk sosial. Peran sosial manusia ini berlangsung secara alami, karena manusia tidak akan mampu bertahan hidup tanpa bantuan dari manusia lainnya. Manusia akan selalu berinteraksi, berkomunikasi dengan sesamanya dalam upaya pemenuhan kebutuhan hidupnya. Menurut penelitian, seseorang menghabiskan hampir 70\% waktu kesehariannya untuk berkomunikasi. Jadi komunikasi merupakan konsekuensi hubungan sosial manusia.

Komunikasi sebagai suatu realitas yang sering dilakukan manusia memiliki begitu banyak definisi yang telah dilahirkan oleh para ahli dan pakar komunikasi. Definisi-definisi tersebut sangat beragam dan dilatar belakangi oleh berbagai perspektif .Berikut definisi umum komunikasi yang meliputi definisi secara etimologis dan terminologis serta definisi komuniskasi secara paradigmatis.

\section{Pengertian Komunikasi Interpersonal Definisi Komunikasi Interpersonal}

Komunikasi Interpersonal merupakan salah satu dari bentuk komunikasi. Komunikasi interpersonal sebenarnya adalah suatu proses sosial, dimana orang-orang yang terlibat di dalamnya saling mempengaruhi. Seperti didefinisikan oleh Josep A. Devito dalam bukunya “The Interpersonal Communication Book" (1991:4). 
"Interpersonal communication as the sending of messages by one person and the receiving of messages by another person, of small group of person, eith some effect and some immediate feedback".

Rogers mengatakan seperti yang dikutip oleh Liliweri (1991:12) bahwa komunikasi interpersonal merupakan komunikasi dari mulut ke mulut yang terjadi dalam interaksi tatap muka antara beberapa pribadi”.

Dalam situasi komunikasi seperti ini komunikator dapat mengkaji diri komunikan secara langsung. Komunikator dapat mengatahui efek komunikasi pada saat itu dan umpan balik terjadi secara langsung, sehingga tidak mungkin tidak mengetahui respon komunikan.

Menurut Sastropoetro (1987:33) bahwa; "Komunikasi interpersonal adalah komunikasi yang dilakukan antara seseorang dengan orang lain yang memungkinkan adanya dialog antar keduanya, dan pada umumnya bersifat akrab, terbuka, dan dapat menantapkan suatu pengertian tentang suatu hal".

Pada umumnya komunikasi interpersonal dilakukan untuk mempengaruhi, mengubah pendapat, sikap, serta tingkah laku mengenai sasaran atau tujuan yang diharapkan. Jika sasaran atau tujuan tersebut telah tercapai, maka komunikasi interpersonal yang terjadi dapat dikatakan berhasil.

\section{Pengertian Kecakapan Komunikasi Interpersonal}

Pada umumnya komunikasi interpersonal dilakukan untuk mempengaruhi, sehingga mengenai sasaran atau tujuan yang diharapkan. Jika sasaran atau tujuan dari berkomunikan tersebut sudah tercapai maka dapat dikatakan bahwa komunikasi interpersonal tersebut telah efektif, atau dengan kata lain kemampuan komunikasi interpersonal yang dimiliki orang tersebut sudah cakap.

Hal ini sesuai dengan pendapat Soemiati (1987:48) bahwa ; "Komunikan dapat dikatakan telah efektif bilamana mengenai sasaran atau mencapai tujuan sesuai dengan yang dimaksud". Sedangkan yang dimaksud mengenai sasaran atau mencapai tujuan yaitu apabila tujuan untuk mengubah pendapat, sikap dan tingkah laku komunikasi dapat tercapai, maka komunikasi interpersonal tersebut efektif. Demikian pula yang diungkapkan oleh Liliweri (1991:18) bahwa:"Berkomunikasi, seseorang harus dapat merubah cara berpikir, pendapat, dan perilaku lawan bicaranya".

Hal serupa juga diungkapkan oleh Supraktiknya (1995:42) yang beranggapan bahwa ; "komunikasi yang efektif adalah apabila penerima menginterprestasikan pesan yang diterimanya sebagaimana yang telah 
dimaksud oleh pengirim". Hal ini berarti dalam berkomunikasi jangan sampai pesan yang disampaikan disalah artikan oleh penerima, karena akan mengakibatkan tidak tercapainya tujuan dari komunikasi itu sendiri.

Sikap suportif atau memberi dukungan akan membuat komunikasi berjalan lancar. Dengan sikap suportif komunikator maupun komunikan akan saling menghargai satu sama lain, dan kedua belah pihak akan bersama-sama berusaha memperkecil perbedaan yang baik dalam hal status, kekuasaan, ataupun intelektual. Sikap mendukung ini, dapat diberikan secara langsung maupun tidak langsung. Langsung berarti secara spontan mendukung gagasan yang muncul sedangkan secara tidak langsung dapat berupa kesediaan untuk mendengar, dan menciptakan suasana yang akrab. Kemudian yang terakhir adalah sikap terbuka. Sikap terbuka mencakup beberapa karakteristik antara lain berani membuka diri, menilai pesan secara objektif dengan menggunakan data dan logika, bersedia mengubah kepercayaannya tersebut kurang tepat, mencari informasi dari beberapa sumber, sehingga dapat memunculkan ide-ide baru. Lebih lanjut dalam komunikasi interpersonal Devito (1995:18) mengungkapkan lima karakteristik komunikasi interpersonal yang efektif, yaitu : "Keterbukaan: yaitu adanya kemampuan untuk membuka diri, mengatakan tentang keadaan dirinya sendiri yang semula disembunyikan. Empati : berarti perasaan individu yang merasakan sama seperti yang dirasakan orang lain. Dukungan : situasi yang mendukung akan mengurangi tekanan atau ketakutan dalam berkomunikasi. Rasa positif : apabila seseorang berkomunikasi dengan perasaan negatif, kemungkinan ia akan menyampaikan pesan secara negatif juga. Dan orang lain akan menerimanya secara negatif. Sebaliknya apabila seseorang merasa positif, maka ia akan berkomunikasi secara positif juga. Bila ini terjadi situasi akan mendorong orang berpesan secara aktif dan membuka diri. Kesamaan : kesamaan di sini dimaksudkan dalam hal berbicara dan mendengar. Apabila seseorang berbicara dan mendengar terus maka tidak mungkin komunikasi menjadi efektif. Kesamaan juga dimaksudkan dalam hal tingkat pendidikan, tingkat sosial ekonomi, status dan lain sebagainya”.

\section{KESIMPULAN}

Berdasarkan deskripsi data penelitian dan setelah dilakukan analisis maka dapat disimpulkan : Terdapat pengaruh yang positif dan sangat signifikan motivasi belajar dan kecakapan komunikasi interpersonal secara bersama-sama terhadap prestasi belajar PKn. Secara bersama-sama variabel motivasi belajar dan kecakapan komunikasi Interpersonal memberikan kontribusi sebesar 59 persen. Terdapat pengaruh yang positif dan sangat 
signifikan motivasi belajar terhadap prestasi belajar PKn. Terdapat pengaruh yang positif dan sangat signifikan kecakapan komunikasi interpersonal terhadap prestasi belajar PKn.

\section{DAFTAR PUSTAKA}

Abdulkarim. Aim, 2007. Kewarganegaraan untuk SMA Kelas XI, Jakarta: Pustaka ilmu

Depdiknas RI, 2006. Permendiknas no 23 Tahun 2006. Lampiran Standar Isi. Jakarta : Depdiknas

Dimyati dan Mudjiono. 2009. Belajar dan Pembelajaran. Jakarta: Rineka Cipta

Gagne, Robert M. 1998. Essentials of Learning For Instruction. New Jersy : Englewood Cliffes

Hamalik, Oemar. 20ıo. Proses Belajar Mengajar. Jakarta: Bumi Aksara

Hasibuan, Malayu SP. (2010). Manajemen Sumber Daya Manusia. Jakarta: Bumi Aksara

Lestari, Sudi., 2oı, Teori dan Prinsip Pendidikan, Jakarta : Rineka Cipta

Muizudin. 2003. Pengaruh Pemberian Evaluasi Formatif Terhadap Hasil Belajar IPA Ditinjau Dari Sikap Siswa Terhadap Mata Pelajaran IPA. Tesis, Jakarta : UNJ

Sardiman A.M., Interaksi dan Motivasi Belajar Mengajar, (Jakarta: CV. Rajawali Press, 2010)

Setiawati, N.T. 1996. Hubungan antara Intelegensi, Kreativitas, dan Motivasi Berprestasi dengan prestasi belajar pada Siswa SMUN 8 Jakarta. Skripsi tidak diterbitkan. Fakultas Psikologi Unitersitas Indonesia, Depok

Slameto. 2003. Belajar Dan Faktor-Faktor Yang mempengaruhinya, Jakarta: Rineka Cipta

Sudjana, Nana. 2004. Dasar-dasar Proses Belajar Mengajar. Bandung : Sinar Baru

Uno, H. Hamzah B. 2007. Profesi kependidikan. Problema, Solusi dan Reformasi Pendidikan di Indonesia. Jakarta : Bumi Aksara

Winkel, W.S. 1999. Psikologi Pengajaran, Edisi yang disempurnakan, cetakan ke-4, Jakarta: Grasindo 

